American Journal of Biochemistry and Biotechnology 7 (1): 32-42, 2011

ISSN 1553-3468

(C) 2010 Science Publications

\title{
Basal Salt Requirements Differ According to Culture Stage and Cultivar in Date Palm Somatic Embryogenesis
}

\author{
Jameel M. Al-Khayri \\ Department of Agricultural Biotechnology, College of Agricultural and Food Sciences, \\ King Faisal University, Al-Hassa 31982, Saudi Arabia
}

\begin{abstract}
Problem statement: Various media formulations differing in basal salt composition are arbitrary selected to provide essential nutrients for plant in vitro cultures. Evidence suggests that in vitro response to various media formulations varies among genotypes and depends on the culture stage. This study examined the efficacy of five basal salt formulations on callus growth and somatic embryogenesis in date palm Phoenix dactylifera L. using three commercial cultivars, Khusab, Berny and Barhee. Approach: Callus from shoot tip explants maintained on MS medium was introduced to various media formulations including $\mathrm{SH}, \mathrm{W}, \mathrm{MS}, \mathrm{WPM}$ and NN media containing $53.7 \mu \mathrm{M}$ NAA and $7.4 \mu \mathrm{M} 2 \mathrm{iP}$. To assess the effect on callus growth, fresh callus weight was measured 4 and 8 weak later. To evaluate embryogenesis response, callus was transferred to hormone-free media corresponding to those during callus growth stage. Results: The optimum medium formulation varied according to cultivar and culture stage. Extending callus growth to 8 weak allowed for greater discernment of differences as compared to 4 weak because of the inherent slow growth nature of date palm callus. The best callus growth was achieved in cv. Khusab using W and WPM media, cv. Berny using SH and NN medium and cv. Barhee using SH, W and MS media. An optimal medium for callus growth was not necessarily the best for somatic embryogenesis. The highest regeneration percentage in cv. Berny occurred on WPM medium, cv. Khusab on W medium and cv. Barhee using W and WPM media. The highest number of resultant embryos was achieved in cv. Khusab using W and SH media, cv. Berny on WPM and MS media and cv. Barhee using W and SH media. Conclusion: This study provides important information to optimize medium formulation in micropropagation protocols of various date palm cultivars, particularly recalcitrant genotypes. It showed that the best basal salt formulation differed among date palm genotypes and suggested culture stage-specific requirement.
\end{abstract}

Key words: Callus growth, In vitro, optimum medium, palm micropropagation, Phoenix dactylifera, plant tissue culture, plant regeneration, somatic embryogenesis, commercial cultivars, vegetative propagation

\section{INTRODUCTION}

Date palm (Phoenix dactylifera L.), a monocotyledonous, dioecious tree species belonging to Arecaceae family, is a major agricultural crop cultivated in the hot, arid regions of the world, mainly in the Middle East and North Africa. It contributes to a sustainable agricultural system in areas where it is grown and plays important social and economic roles (Zohary and Hopf, 2000). Propagation by seeds produce off-type plants and vegetative propagation by offshoots has numerous limitations related to availability and field survivability. Alternatively, micropropagation has gained acceptance for largescale propagation and commercial production of date palm trees. In addition, it offers controlled conditions for studying aspects of physiological and genetic improvement.

Micropropagation of date palm has been achieved from several genotypes through organogenesis and somatic embryogenesis using various meristematic explants including zygotic embryos, shoot tips and lateral buds (Omar et al., 1992; Al-Khayri, 2005; 2007). Somatic embryogenesis is considered as the most efficient regeneration process for date palm micropropagation (El Hadrami and Baziz, 1995; AlKhayri, 2001; Fki et al., 2003). Several studies were conducted to optimize somatic embryogeneis of date palm through the manipulation of culture medium ingredients including amino acids (Abo El-Nil, 1989a; Abdel-Rahim et al., 1998; El-Shiaty et al., 2004; Zouine and El Hadrami, 2007), plant growth regulators 
Omar et al., 1992; Eshraghi et al., 2005; Zouine and El Hadrami, 2007), physical status (Veramendi and Navarro, 1996; Taha et al., 2001; Fki et al., 2003), sucrose (Veramendi and Navarro, 1996; Taha et al., 2001; Alkhateeb, 2008), silver nitrate as an inhibitor of ethylene (Al-Khayri and Al-Bahrany, 2001; 2004), biotin and thiamine (Al-Khayri, 2001; El-Shiaty, et al. 2004), salt strength (Taha et al., 2001; Al-Khayri, 2003) and coconut water (Al-Khayri, 2010). In addition, Othmani et al. (2009) enhanced plant regeneration through partial desiccation of somatic embryos.

These studies have contributed to understanding the effects of a variety of medium components and culture conditions leading to enhanced plant regeneration. It is imperative to investigate other culture medium components to further enhance and expedite regeneration capacity, especially for recalcitrant date palm genotypes. The formation, devolvement and germination of somatic embryos are controlled by basal salt composition among other known tissue culture factors. Protocols of somatic embryogenesis often use only one medium formulation during the entire process, even though this formulation may not be optimal for the various stages of the micropropagation process. A complete nutrient medium contains defined amounts of minerals, in the form of inorganic salts, essential for in vitro growth and development. Nevertheless, studies related to mineral nutrients have been limited and often focused on growth responses thus overlooking their role as morphogenic elicitors (Ramage and Williams, 2002). A wide range of formulations of macro-and micro-salt mixtures have been arbitrarily selected as a basal nutrient medium in different plant species. Comparative studies of various culture medium formulations on different in vitro culture stages of date palm are scarce. So far, two studies have been carried out on basal salt formulation of date palm tissue culture medium (Sharma et al., 1980; Abo El-Nil, 1989b). Both studies neglected to mention the cultivars used, a highly influential factor controlling in vitro morphogenic responses. The former study involved testing callus induction from various explants and the latter addressed also studied the callus induction stage as well as somatic embryogenesis stage. The current study was conducted to assess the effects of a different set of basal salt formulations on callus growth (multiplication) and somatic embryogenesis stages using a different set of basal media. The best media formulation for each of these stages was determined. In addition, this study asserted genotypic differences in response to the various basal salt media using three commercial date palm cultivars, Khusab, Berny and Barhee.

\section{MATERIALS AND METHODS}

Explant preparation and culture establishment: Offshoots derived from 3-year-old date palm commercial cultivars (Khusab, Berny and Barhee) obtained from a local farm were dissected to expose the shoot tip region which was excised, about $8 \mathrm{~cm}$ long and surface sterilized in $70 \%$ ethanol for $1 \mathrm{~min}$ followed by $15 \mathrm{~min}$ in $1.6 \% \mathrm{w} / \mathrm{v}$ sodium hypochlorite (30\% v/v Clorox, commercial bleach) containing 3 drops of Tween 20 per $100 \mathrm{~mL}$ solution. The tissue was then rinsed with sterile distilled water four times to remove traces of disinfectant. For preventing tissue browning, place it in a sterile chilled antioxidant solution, consisting of ascorbic acid and citric acid, 150 $\mathrm{mg} \mathrm{L}^{-1}$ each. The tissue surrounding the shoot tips was aseptically removed to expose the shoot tip terminal, about $1 \mathrm{~cm}$ long, which was cut longitudinally into 4-8 segments to serve as explants.

Callus initiation and maintenance: Explants were cultured on a medium consisting of MS salts (Murashige and Skoog, 1962) supplemented with ingredients listed in Table 1. The medium was adjusted to $\mathrm{pH} 5.7$ with $1 \mathrm{~N} \mathrm{KOH}$, dispensed in $25 \times 150-\mathrm{mm}$ culture tubes (15 ml per tube) and autoclaved for 15 min at $121^{\circ} \mathrm{C}$ and $1 \times 10^{5} \mathrm{~Pa}\left(1.1 \mathrm{~kg} \mathrm{~cm}^{-2}\right)$. Hormones and activated charcoal were added according to the requirement of each culture stage as listed in Table 2.

Table 1: Constituents of additives supplemented to the basal media formulations

\begin{tabular}{ll}
\hline Constituents & $\begin{array}{l}\text { Final concentration } \\
\text { in culture medium } \\
\left(\mathrm{mg} \mathrm{L}^{-1}\right)\end{array}$ \\
\hline $\begin{array}{l}\text { Additional salt } \\
\mathrm{NaH}_{2} \mathrm{PO}_{4}\end{array}$ & 170 \\
Vitamins & 125 \\
Myo-inositol & 1 \\
Nicotinic acid & 1 \\
Pyridoxine hydrochloride & 1 \\
Thiamine hydrochloride & 2 \\
Glycine & 1 \\
Calcium pantothenate & 1 \\
Biotin & \\
Antioxidants & 200 \\
Glutamine & 100 \\
Ascorbic acid & 100 \\
Citric acid & \\
Sugar and solidifying agent & 40,000 \\
Sucrose & 7,000 \\
Agar & \\
Hormones and activated charcoal & \\
2,4-D, NAA, 2-iP, kinetin & According to the culture \\
Activated charcoal & stage as described Table 2 \\
\hline &
\end{tabular}


Am. J. Biochem. \& Biotech., 7 (1): 32-42, 2011

Table 2: Hormones and activated charcoal supplemented to the culture media in various phases of date palm indirect somatic embryogenesis

\begin{tabular}{|c|c|c|c|c|c|c|}
\hline Additive & $\begin{array}{l}\text { Culture } \\
\text { initiation } \\
\end{array}$ & $\begin{array}{l}\text { Callus } \\
\text { induction }\end{array}$ & $\begin{array}{l}\text { Embryogenic } \\
\text { callus }\end{array}$ & $\begin{array}{l}\text { Callus } \\
\text { maintenance }\end{array}$ & $\begin{array}{l}\begin{array}{l}\text { Somatic } \\
\text { embryogenesis }\end{array} \\
\end{array}$ & Rooting \\
\hline 2,4-Dichlorophenoxyacetic acid (2,4-D) & $\begin{array}{l}100 \mathrm{mg} \mathrm{L}^{-1} \\
(453 \mu \mathrm{M})\end{array}$ & - & - & - & - & - \\
\hline 2-Isopentenyladenine (2iP) & $\begin{array}{l}3 \mathrm{mg} \mathrm{L}^{-1} \\
(15 \mu \mathrm{M})\end{array}$ & $\begin{array}{l}30 \mathrm{mg} \mathrm{L}^{-1} \\
(147 \mu \mathrm{M})\end{array}$ & $\begin{array}{l}6 \mathrm{mg} \mathrm{L} \mathrm{L}^{-1} \\
(30 \mu \mathrm{M})\end{array}$ & $\begin{array}{l}1.5 \mathrm{mg} \mathrm{L}^{-1} \\
(7 \mu \mathrm{M})\end{array}$ & - & - \\
\hline Naphthaleneacetic acid (NAA) & - & $\begin{array}{l}10 \mathrm{mg} \mathrm{L}^{-1} \\
(54 \mu \mathrm{M})\end{array}$ & $\begin{array}{l}10 \mathrm{mg} \mathrm{l}^{-1} \\
(54 \mu \mathrm{M})\end{array}$ & $\begin{array}{l}10 \mathrm{mg} \mathrm{L}^{-1} \\
(54 \mu \mathrm{M})\end{array}$ & - & $\begin{array}{l}0.1 \mathrm{mg} \mathrm{L}^{-1} \\
(0.54 \mu \mathrm{M})\end{array}$ \\
\hline Activated charcoal & $1.5 \mathrm{~g} \mathrm{~L}^{-1}$ & $1.5 \mathrm{~g} \mathrm{~L}^{-1}$ & $1.5 \mathrm{~g} \mathrm{~L}^{-1}$ & - & - & - \\
\hline
\end{tabular}

Table 3: The chemical composition of the various basal salt media tested in date palm callus multiplication and somatic embryogenesis

\begin{tabular}{|c|c|c|c|c|c|}
\hline \multirow[b]{2}{*}{ Constituents } & \multicolumn{5}{|c|}{ Concentration in media formulations $\left(\mathrm{mg} \mathrm{L}^{-1}\right)$} \\
\hline & MS & SH & W & $\mathrm{NN}$ & WPM \\
\hline $\mathrm{Ca}\left(\mathrm{NO}_{3}\right)_{2} \cdot 4 \mathrm{H}_{2} \mathrm{O}$ & - & - & 300 & - & 556 \\
\hline $\mathrm{CaCl}_{2} 2 \mathrm{H}_{2} \mathrm{O}$ & 440 & 200 & - & 166 & 96 \\
\hline $\mathrm{CoCl}_{2} \cdot 6 \mathrm{H}_{2} \mathrm{O}$ & 0.025 & 0.1 & - & - & - \\
\hline $\mathrm{CuSO}_{4} \cdot 5 \mathrm{H}_{2} \mathrm{O}$ & 0.025 & 0.2 & - & 0.025 & 0.25 \\
\hline $\mathrm{Fe}_{2}\left(\mathrm{SO}_{4}\right)_{3}$ & - & - & 2.5 & - & - \\
\hline $\mathrm{FeSO}_{4} \cdot 7 \mathrm{H}_{2} \mathrm{O}$ & 27.8 & 15 & - & 27.8 & 27.8 \\
\hline $\mathrm{H}_{3} \mathrm{BO}_{3}$ & 6.2 & 5 & 1.5 & 10 & 6.2 \\
\hline $\mathrm{KCl}$ & - & - & 65 & - & - \\
\hline $\mathrm{KH}_{2} \mathrm{PO}_{4}$ & 170 & - & - & 68 & 170 \\
\hline $\mathrm{KI}$ & 0.83 & 1 & 0.75 & - & - \\
\hline $\mathrm{KNO}_{3}$ & 1900 & 2500 & 80 & 950 & - \\
\hline $\mathrm{K}_{2} \mathrm{SO}_{4}$ & - & - & - & - & 990 \\
\hline $\mathrm{MgSO}_{4} \cdot 7 \mathrm{H}_{2} \mathrm{O}$ & 370 & 400 & 720 & 185 & 370 \\
\hline $\mathrm{MnSO}_{4}$ & 16.9 & - & 7 & - & - \\
\hline $\mathrm{MnSO}_{4} \cdot \mathrm{H}_{2} \mathrm{O}$ & - & 10 & - & 25 & 22.3 \\
\hline $\mathrm{Na}_{2}$ EDTA $2 \mathrm{H}_{2} \mathrm{O}$ & 37.3 & - & - & 37.3 & 37.3 \\
\hline $\mathrm{Na}_{2}$ EDTA & - & 20 & - & - & - \\
\hline $\mathrm{Na}_{2} \mathrm{MoO}_{4} 2 \mathrm{H}_{2} \mathrm{O}$ & 0.25 & 0.1 & - & 0.25 & 0.25 \\
\hline $\mathrm{Na}_{2} \mathrm{SO}_{4}$ & - & - & 200 & - & - \\
\hline $\mathrm{NaH}_{2} \mathrm{PO}_{4} 2 \mathrm{H}_{2} \mathrm{O}$ & 170 & - & - & - & - \\
\hline $\mathrm{NaH}_{2} \mathrm{PO}_{4} \mathrm{H}_{2} \mathrm{O}$ & - & - & 16.5 & - & - \\
\hline $\mathrm{NaH}_{2} \mathrm{PO}_{4}$ & - & 300 & - & - & - \\
\hline $\mathrm{NH}_{4} \mathrm{NO}_{3}$ & 1650 & - & - & 720 & 400 \\
\hline $\mathrm{ZnSO}_{4} \cdot 7 \mathrm{H}_{2} \mathrm{O}$ & 8.6 & 1 & 3 & 10 & 8.6 \\
\hline Reference & $\begin{array}{l}\text { Murashige and } \\
\text { Skoog } 1962\end{array}$ & $\begin{array}{l}\text { Schenk and } \\
\text { Hildebrandt (1972) }\end{array}$ & White (1963) & $\begin{array}{l}\text { Nitsch and } \\
\text { Nitsch (1969) }\end{array}$ & $\begin{array}{l}\text { Lloyd and } \\
\text { McCown (1981) }\end{array}$ \\
\hline
\end{tabular}

After 12 weak, explants with resultant callus attached were cultured on callus proliferation medium. After 3 weak, callus was separated from original explants and subcultured to embryogenic callus medium. After 9 weak, embryogenic callus was transferred to multiplication medium for callus maintenance. Throughout these stages, cultures were maintained in darkness at $24 \pm 3^{\circ} \mathrm{C}$ and transferred at a 3 -weak interval. Cultures maintained for 16 weak served as the source of callus for the current comparative study.

Effect of different medium formulations on callus growth: To evaluate callus growth in response to various tissue culture media formulations, five popular media salt formulations were tested including $\mathrm{SH}$ medium (Schenk and Hildebrandt, 1972), W medium
(White, 1963), MS medium (Murashige and Skoog, 1962), WPM (Woody Plant Medium; Lloyd and McCown, 1981) and NN medium (Nitsch and Nitsch, 1969). The composition of these basal salts is listed in Table 3. Additives were standardized in all media (Table 1). For callus growth evaluation, these media also contained $10 \mathrm{mg} \mathrm{L}^{-1} \mathrm{NAA}(53.7 \mu \mathrm{M})$ and $1.5 \mathrm{mg}$ $\mathrm{L}^{-1} 2 \mathrm{iP}(7.4 \mu \mathrm{M})$. Each cultures tube was inoculated with $0.3 \mathrm{~g}$ callus from the maintenance cultures. The cultures were incubated in complete darkness at $24 \pm 3^{\circ} \mathrm{C}$ for 8 weak during which calli were weighed and transferred to fresh media at a 4 weak interval. To determine callus growth, the calli were weighed after 4 and 8 weak.

Effect of different medium formulations on somatic embryogenesis: To evaluate somatic embryogenesis in 
Am. J. Biochem. \& Biotech., 7 (1): 32-42, 2011

response to various tissue culture media formulations, calli maintained on the five media were transferred to the corresponding media formulations devoid of hormones. These cultures were maintained at $24 \pm 3^{\circ} \mathrm{C}$ and a 16-h photoperiod $\left(50 \mu \mathrm{mol} \cdot \mathrm{m}^{-2} \cdot \mathrm{s}^{-1}\right)$ provided from cool-white fluorescent lamps for 8 weak during which they were transferred to fresh media every 4 weak. After 12 weak, the regeneration percentage and number of resultant somatic embryos were recorded.

Embryo germination and plant establishment: The resultant somatic embryos were transferred to a hormone-free MS medium and incubated at $24 \pm 3^{\circ} \mathrm{C}$ and a $16 \mathrm{~h}$ photoperiod. After 8 weak, the germinated embryos were transferred to MS medium containing 0.1 $\mathrm{mg} \mathrm{L}^{-1}(0.54 \mu \mathrm{M})$ NAA and dispensed at $15 \mathrm{~mL}$ per $25 \times 120 \mathrm{~mm}$ culture tubes. For gradual acclimatization, the plantlets were placed vertically in beakers containing a sufficient amount of water to submerge the roots, kept in the culture room covered with transparent plastic bags for 2 weak. Plantlets were then transplanted into $5-\mathrm{cm}$ plastic pots containing potting mix (1 soil: 1 peat moss: 1 vermiculite) and watered with $100 \mathrm{mg} \mathrm{L}^{-1}$ Peters (20-20-20) fertilizer (Grace-Sierra). Potted plantlets were covered with plastic bags, watered as needed, uncovered gradually during the next 6 weak and then transferred to a greenhouse for further growth.

Experimental design and statistical analysis: To examine callus growth, in terms of fresh weight, in response to various tissue culture media formulations, the experiment was set up as a completely randomized 2 -factor factorial design with the main factors being media basal salt formulation at 5 levels and cultivar at 3 levels. Data were based on 10 replications per treatment and proportional data were based on 3 replications consisting of 10 cultures each. Transformation of proportional data was not necessary. Data pertaining to callus weight measured after 4 and 8 weak, percentage of cultures exhibiting somatic embryogenesis and numbers of resultant somatic embryos were subjected to Analysis Of Variance (ANOVA). Means were separated, where appropriate, with a Least Significant Difference (LSD) at 5\% significance level.

\section{RESULTS}

Callus growth: According to an analysis of variance, embryogenic callus growth measured 4 weak after treatment was significantly influenced by a two-way interaction between medium formulation and cultivar
(Table 4). This means that individual cultivars responded differently to the dissimilar salt composition of the culture media. Cultivar Berny, which exhibited the lowest callus growth and subsequent plant regeneration, appeared to be unaffected by the change in salt composition (Fig. 1A), while the other two cultivars reacted differently depending upon the formulation. In cv. Khusab, SH and MS media gave the highest callus growth; however, other media used gave closely comparative results. In contrast, cv. Barhee grew best on W and MS media, while using WPM and $\mathrm{NN}$ media reduced callus growth.

Extending the culture duration to 8 weak resulted in more callus proliferation (Fig. 1B); thus allowing an easier and higher precision comparison of differences in response. This was indicated by a stronger P-value revealed by the analysis of variance of callus growth measured after 8 weak of treatment (Table 4). This suggests that although 4 weak was sufficient to detect differences, discerning the efficacy of various media formulations, especially difficult to detect small differences, can be better achieved by extending the treatment to 8 weak. This finding would facilitate developing a screening method to evaluate the response of the numerous date palm genotypes to various media formulations in future studies.

After 8 weak culture duration cv. Berny callus grew better on $\mathrm{SH}$ and $\mathrm{NN}$ media as compared to the other formulations tested. This difference was undetectable after only 4 weak of treatment. In cv. Khusab, suitability of W and WPM media ranked first, $\mathrm{SH}$ and MS medium ranked second and NN ranked third. Comparatively, cv. Barhee callus grew best on SH, W and MS media, while MS gave moderate growth and WPM and NN medium appeared to be least suitable. These responses more accurately depict the effect of various culture medium formulations as the differences become larger and more pronounced in comparison to observations made after 4 weak of treatment.

Percentage of regeneration: Upon transfer to hormone-free regeneration medium, callus began to redifferentiate and develop somatic embryos. An important indicator of the suitability of a culture medium is the regeneration percentage, i.e., the proportion of cultures that formed somatic embryos. According to an analysis of variance (Table 4), these percentages were affected by a significant two-way interaction between the main factors, medium formulation and cultivar. This means that date palm cultivars responded differently to dissimilar media formulations, as illustrated in Fig. 1C. 
Am. J. Biochem. \& Biotech., 7 (1): 32-42, 2011

Table 4: Analysis of variance of the effect of medium formulation and cultivar on callus growth after 4 and 8 weak expressed in fresh weight, percentage of regeneration and number of resultant somatic embryos. P-values less than 0.05 are significant

\begin{tabular}{|c|c|c|c|c|c|c|}
\hline \multirow[b]{2}{*}{ Factor } & \multicolumn{3}{|c|}{ Callus weight after 4 weak } & \multicolumn{3}{|c|}{ Callus weight after 8 weak } \\
\hline & DF & MS & P Value & DF & MS & P Value \\
\hline Medium & 4 & 0.026 & 0.0122 & 4 & 0.091 & 0.012 \\
\hline Cultivar & 2 & 0.518 & 0.0001 & 2 & 1.056 & 0.0001 \\
\hline Medium $\mathrm{x}$ cultivar & 8 & 0.02 & 0.011 & 8 & 0.076 & 0.007 \\
\hline \multirow[t]{2}{*}{ Error } & 135 & 0.008 & & & 135 & 0.027 \\
\hline & \multicolumn{3}{|c|}{--------------Percentage of regeneration--------------- } & \multicolumn{3}{|c|}{----------Number of somatic embryos----.-- } \\
\hline Medium & 4 & 611.111 & 0.0671 & 4 & 831.083 & 0.0001 \\
\hline Cultivar & 2 & 4862.222 & 0.0001 & 2 & 5188.22 & 0.0001 \\
\hline Medium $\mathrm{x}$ cultivar & 8 & 759.444 & 0.012 & 8 & 762.878 & 0.0001 \\
\hline Error & 30 & 248.889 & & 135 & 31.287 & \\
\hline
\end{tabular}

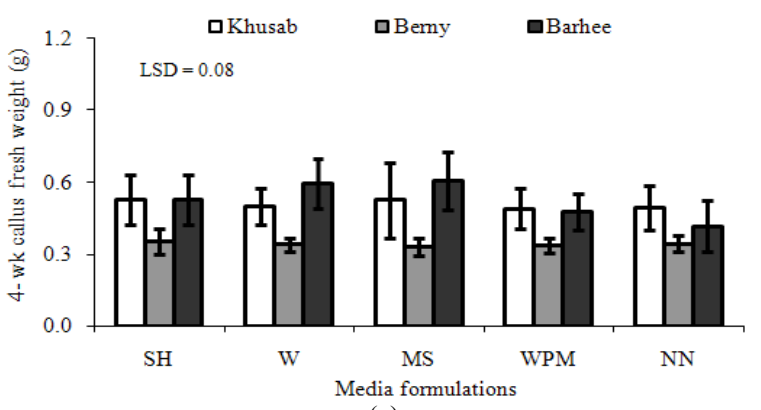

(a)

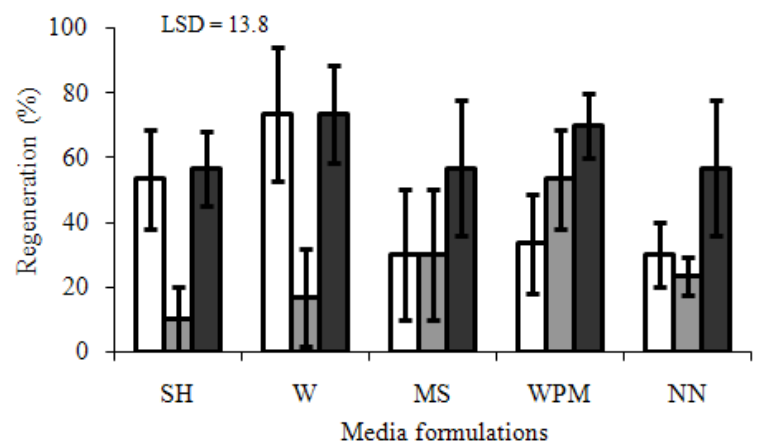

(c)

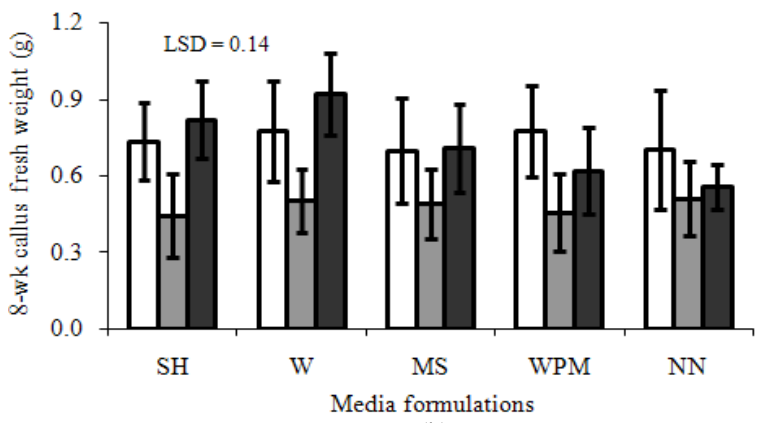

(b)

Fig. 1: Date palm cultivars to culture media formulations, SH medium (Schenk and Hildebrandt, 1972), W (White 1963), MS medium (Murashige and Skoog, 1962), WPM (Lloyd and McCown 1981) and NN medium (Nitsch and Nitsch, 1969). (a) Callus growth expressed in fresh weight after 4 weak of treatment; (b) Callus weight after 8 weak; (c) Somatic embryogenesis expressed in percentage of regeneration; (d) Number of resultant somatic embryos

In cv. Khusab, the highest percentage regeneration was achieved on $\mathrm{W}$ followed by $\mathrm{SH}$ medium, while significantly lower percentages were associated with $\mathrm{W}, \mathrm{MS}$ and NN media. Conversely, cv. Berny produced highest regeneration on WPM, followed by MS and $\mathrm{NN}$, while least regeneration was associated with $\mathrm{SH}$ and $\mathrm{W}$ media. Comparatively, maximum percentage of regeneration in cv. Barhee was obtained on $\mathrm{W}$ and WPM, followed by SH, MS and NN media. This cultivar seems to be more adaptable to the widest range of media formulations since it sustained high regeneration percentages in all tested formulations (Fig. 1C).

Number of somatic embryos: As another indicator of the suitability of a given culture medium formulation is the number of resultant somatic embryos as a measure of the potency of somatic embryogenesis. According to an analysis of variance (Table 4), the number of resultant somatic embryos was influenced by a significant two-way interaction between medium formulation and cultivar. 
Am. J. Biochem. \& Biotech., 7 (1): 32-42, 2011

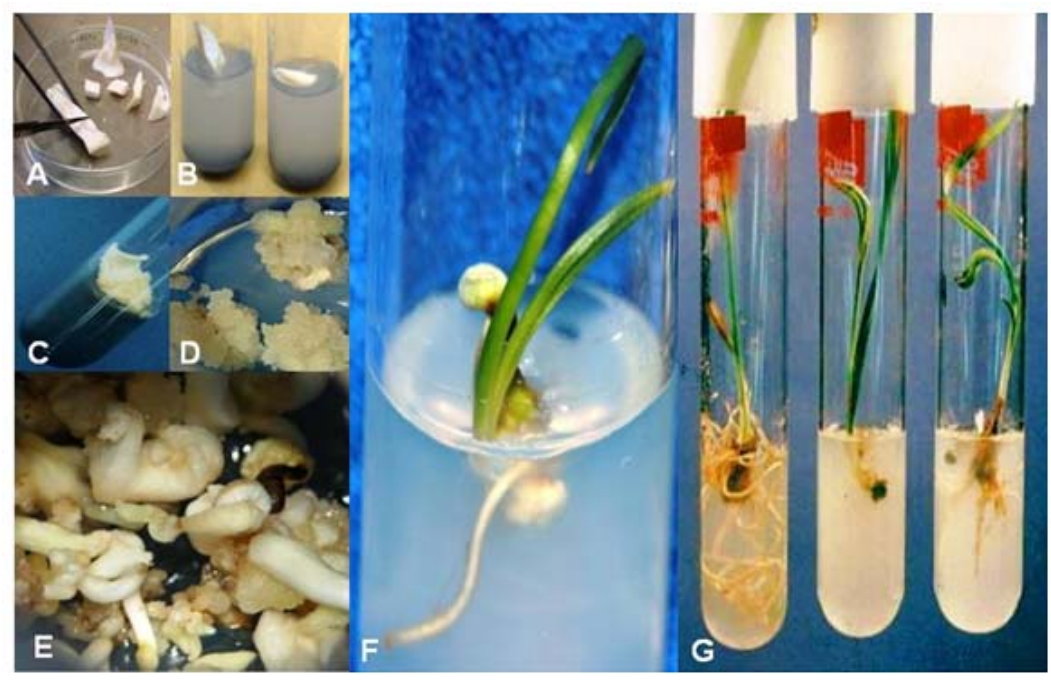

Fig. 2: Consecutive stages of date palm somatic embryogenesis: a Explant isolation from shoot tip; b Explant establishment on culture medium; c Callus induction; d Callus multiplication cultures; e Development of somatic embryos; f Germinated embryo showing shoot and root initiation, $g$ Rooted plantlets ready for transplanting

In cv. Khusab, the highest number of resultant embryos was achieved on W closely followed by SH; MS ranked next and was moderate, while significantly lower numbers were associated with $\mathrm{NN}$ and $\mathrm{W}$ media (Fig. 1D). In contrast, cv. Berny produced the highest number of embryos on WPM and MS, while the least number of embryos was associated with $\mathrm{NN}, \mathrm{SH}$ and W. Comparatively, the maximum number of embryos in cv. Barhee was obtained on $\mathrm{W}$ and $\mathrm{SH}$ media, followed by WPM, MS and NN media. It is noteworthy to mention that in most cases where the medium formulation gave high regeneration percentages, high numbers of somatic embryos also were produced as shown in Fig. 1C and D, respectively.

Embryo germination and plant establishment: The current experiment focused on the effect of various media formulations on both callus multiplication and somatic embryogenesis stages. Thus, these formulations were not tested during preceding or subsequent stages. Further experiments would be required to determine the effect of media formulations on other culture stages such as somatic embryo maturation, germination and rooting. The current study has shown that the resultant somatic embryos germinated and rooted at approximately 60 and $75 \%$, respectively, regardless of the embryo source. The plantlets obtained exhibited phenotypically normal growth in the greenhouse. More research is required to evaluate the effect of media formulations on somatic embryo germination and root formation. The different stages of date palm somatic embryogenesis starting from explants to plantlets are illustrated in Fig. 2.

\section{DISCUSSION}

The current study compared various media formulations to test the response of date palm genotypes during the stages of callus growth and somatic embryogenesis in order to contribute to the improvement of plant regeneration, particularly of recalcitrant date palm genotypes. Recalcitrance can be a major limiting factor for the biotechnological exploitation of economically-important plant species. Overcoming recalcitrance in difficult genotypes can be greatly assisted by optimization of the key medium components, including modifying the basal salt composition (Benson, 2000).

Although, MS medium is the most commonly used for date palm micropropagation, other basal salt formulations are occasionally used. For instance, B5 medium basal salt (Gamborg et al., 1968) was employed by Sharma et al. (1986) for establishment of suspension culture and a combination of B5 macrosalts and MS microsalts was used by Abul-Soad et al. (2008) for somatic embryo regeneration from inflorescence explants.

Studies comparing the effect of basal salts composition on various stages of date palm micropropagation are rare. A study by Sharma et al. 
Am. J. Biochem. \& Biotech., 7 (1): 32-42, 2011

(1980) addressed this effect on the callus initiation stage. They tested explant response to several media formulations, including MS, NN, SH, S (Staritsky, 1970), AB and Y3 (Eeuwens, 1976). Their results showed that the best callus induction was obtained using medium $\mathrm{S}$ followed by medium Y3. The other media tested failed to form callus and none of the treatments was evaluated in relation to somatic embryogenesis.

In another study, conducted by Abo El-Nil, (1989a), different basal media including MS, SH, HE, W, ER (Ericksson, 1965) and B5 were assessed to their ability to promote callus induction and somatic embryogenesis date palm. It was concluded that callus induction was best using SH and MS media; whereas, the highest somatic embryo numbers were obtained using SH and ER media. Using SH and ER media was more effective for the induction of somatic embryogenesis as compared to MS and B5 media. Both of the preceding investigations, however, omitted the name of cultivars tested and callus multiplication stage was not assessed.

The present study indicated that the in vitro response of date palm to the basal salt formulations was significantly related to the genotype in addition to culture stage. The results obtained clearly show that the best medium for callus growth differed from that best supported somatic embryo formation depending on the cultivar. The best callus growth in cv. Berny occurred on SH and NN, cv. Khusab on W and WPM media and cv. Barhee on SH, W and MS media (Fig. 1B). These differences illustrate cultivar specify of basal salt requirements. Similarly, (Jain et al., 1989) found that genotype and culture medium are critical factors for the production of embryogenic callus in slash pine (Pinus elliottii).

In addition, the data have shown that the best basal medium for callus growth differed from that required for optimum somatic embryogenesis. The highest number of somatic embryos occurred in cv. Khusab using $\mathrm{W}$ medium, cv. Berny using WPM and MS and cv. Barhee using $\mathrm{W}$ and SH (Fig. 1D). These differences highlight the importance of considering the roles of genotype specificity and culture stage in relation to the basal salt requirements when optimizing plant micropropagation schemes. Because of the well recognized role of the hormonal content in modifying in vitro activities, it is relevant to note that the hormonal content used by Abo El-Nil (1989b), $50 \mu \mathrm{M}$ NAA for callus induction and $5 \mu \mathrm{M}$ NAA for somatic embryogenesis, differed from those used in the current study, 53.7 $\mu \mathrm{M}$ NAA and $7.4 \mu \mathrm{M} 2 \mathrm{iP}$ for callus multiplication and no hormones for somatic embryogenesis media.
The current study adds to the mounting evidence of the variable influence of different culture mineral formulations on in vitro growth and morphogenesis demonstrated in a number of plant species (Fisichella et al., 2000; Nas and Read, 2004; Sul and Korban, 2004; Andreu and Marin, 2005). The best salt formulation varies among plant species. In rice, Khatun et al. (2003) found the best callus induction on MS medium as compared to N6 (Chu et al., 1975). The effect of different culture media formulations on the formation of embryo was demonstrated by Bonga (2004) in the European larch tree, Larix decidua where the best medium found was AFC medium (Klimaszewska et al., 2001), a medium low in $\mathrm{NH}_{4}, \mathrm{NO}_{3}, \mathrm{Mg}$ and $\mathrm{SO}_{4}$ but high in $\mathrm{PO}_{4}$. Using nodal explants of rose (Rosa sp.), MS medium resulted in somatic embryo production whereas WP medium did not (Estabrooks et al., 2007). Among the different basal media tried, including MS, B5, LS (Linsmair and Skoog, 1965) and W, MS medium, was found the most suitable for callus induction and plant regeneration in Indian cotton cultivars (Tripathy and Reddy, 2002). The basal salt formulation may influence callus quality in relation to plant regeneration capacity. In a study conducted by Rakshit et al. (2010), immature embryos of maize (Zea mays L.) explants grown on MS medium showed the highest frequency of callusing. However, the best callus quality in term of frequency of organogenic callus was obtained from explants grown on N6 medium.

Although, some tissue culture systems involved different basal salt formulations for different culture stages (Jha et al., 1992), often only one formulation is used for the entire duration of culture systems even though this formulation may be suboptimal for the different stages of growth and development (Ramage and Williams, 2002). In a study to evaluate their ability to support the establishment of callus culture in the medicinal plant Phyllanthus stipulatus, Catapan et al. (2001) tested several basal salt formulations including MS, B5, AR (Anderson, 1978), W, SH, KM (Kao and Michayluk, 1975) and WPM media. They observed shoot initiation in the various salt formulations tested; however, rhizogenesis was completely inhibited except on MS and WPM; whereas, callus initiation occurred only on the MS formulation. The authors suggested that the poor performance of $\mathrm{B} 5, \mathrm{SH}, \mathrm{W}$ and $\mathrm{KM}$ may have been due to their low ammonium content as compared to MS. These results suggest that the optimal salt formulation for a particular culture stage may not be the best for the other culture stages. The present study has shown that media formulations that were observed to be most suitable for callus growth of date palm do not necessarily coincide with optimal formulations for 
somatic embryogenesis. This illustrates that various culture stages may be affected differently by the formulation of the basal media. This was also demonstrated by Capuana et al. (2007) in common ash (Fraxinus excelsior L.) where the best proliferation of embryogenic tissue was obtained when the material was subcultured on MS medium; whereas, WPM medium appeared to be more conducive to faster embryo maturation. In a study on the induction potential of somatic embryos in Eucalyptus globulus involving MS, B5, WPM and DKW (Driver Kuniyuki Walnut medium; Driver and Kuniyuki, 1984), Pinto et al. (2008a) demonstrated that MS and B5 media were the best. In a subsequent study, Pinto et al. (2008b) found that MS medium and B5 were equally effective in the formation of secondary globular somatic embryos; however, MS was more efficient for the germination stage as compared to B5 medium. In the same way, Fisichella et al. (2000) reported that MS medium appeared to be the most favorable for somatic embryo formation in quince (Cydonia oblonga Mill.) as compared to W, WPM, DKW, QL (Quoirin and Lepoivre, 1977), SH, B5 and NN. However, root formation was higher on WPM and SH media.

The current study demonstrated that the response of different genotypes to different formulations varies, indicating an interaction between medium formulation and genotype. The phenomenon of genotype dependency in response to in vitro date palm manipulations is well documented in various plant species (Karami, 2008; Shirani et al., 2010) as well as date palm (Al-Khayri and Al-Bahrany, 2004). The results have shown that the effect of basal media formulations can be influenced by various date palm genotypes. Analogous to this finding, several investigations have shown variable responses of different cultivars to different media formulations in a number of plant species (Khanna and Raina, 1998; Perez-Tomero and Burgos, 2000; Khatun et al., 2003). In oil palm (Elaeis guineensis Jacq.), the highest embryogenic callus formation from zygotic embryo explants, somatic embryogenesis and germination were achieved using N6 medium as compared to MS medium (Thuzar et al., 2010). However, other cultivars of oil palm exhibited the best responses using Y3 medium as compared to N6 and MS media (Muniran et al., 2008). Rafiq et al. (2005) observed interactions between media and different maize (Zea mays L.) genotypes in a study involving callus induction and plant regeneration using various media formulations including MS, LS, B5 and N6. Gonzalez et al. (2001) demonstrated a strong influence of genotype on callus induction and plant regeneration from immature embryos of durum wheat
Triticum turgidum Desf. Similarly, the influence of genotype and media combination on callus growth, somatic embryo regeneration and root formation was also observed in quince Cydonia oblonga Mill. (Fisichella et al., 2000).

\section{CONCLUSION}

Although most of the published protocols of date palm micropropagation use the same medium during the entire process, the results reported here emphasize the importance of the salt content of the culture medium on the different somatic embryogenesis stages. Micropropagation systems can be customized to accommodate the stage specificity requirements by switching between optimal basal media according to the culture stage. This study also illustrated the interaction of medium formulation and genotype. It resulted in an effective protocol for assessment of various tissue culture parameters in response to altering medium components, or other culture conditions. The protocol was useful to detect cultivar differences and determine the optimal media formulations suitable for callus and somatic embryogenesis stages of three date palm cultivars. This investigation has shown that accurate assessments of responses to medium manipulation must consider the specific requirement of various culture stages as well as the genotypic-dependent differences. The assessment procedures developed in this study and the resultant information should assist future research aimed at identifying optimum medium formulation for the numerous date palm cultivars, particularly the recalcitrant genotypes. Further studies are necessary to determine the effect of media formulations on the germination of somatic embryo and rooting parameters.

\section{ACKNOWLEDGMENT}

This study was funded by a research grant (Project no. SABIC-504) provided by the Deanship of Scientific Research, King Faisal University.

\section{REFERENCES}

Abdel-Rahim, E.A., O.M. Abdel-Fatah, H.A. El-Shemy and M.B. Abd El-Samei, 1998. Growth of date palm callus as affected by amino acids as organic nitrogen source. Proceedings of the 1st International Conference Date Palm, Al-Ain, United Arab Emirates, pp: 234-240. www.pubhort.org/datepalm/datepalm1/datepalm1_ 19.pdf 
Abo El-Nil, M., 1989a. The effects of amino acid nitrogen on growth of date palm callus. Proceedings of the 2nd Symposium Date Palm, King Faisal Univ., Al-Hassa, Saudi Arabia, March 1986, pp: 59-65. www.dprckfu.com/english/download_seminar.php ?idd $=78$

Abo El-Nil, M., 1989b. Refining methods for date palm micropropagation. Proceedings of the 2nd Symposium Date Palm, King Faisal Univ. AlHassa, Saudi Arabia, March 1986, pp: 29-41. www.dprckfu.com/english/download_seminar.php ?idd $=75$

Abul-Soad, A.A., G.S. Markhand and S.A. Shah, 2008. Effect of naphthaleneacetic acid and indole-3acetic acid on somatic embryogenesis of female inflorescence explants of date palm (Phoenix dactylifera L.) cv. Aseel. Proceedings of the 3rd International Conference Date Palm. Faculty of Agriculture and Environmental Science, Suez Canal University, North Sinai, Egypt, April 2008, pp: 222-231. www.salu.edu.pk/research/dpri/docs/b-002.pdf

Alkhateeb, A., 2008. Comparison effects of sucrose and date palm syrup on somatic embryogenesis of date palm (Phoenix dactylifera L.). Am. J. Biochem. Biotechnol., 4: 19-23.

DOI: 10.3844/AJBBSP.2008.19.23

Al-Khayri, J.M. and A.M. Al-Bahrany, 2001. Silver nitrate and 2-isopentyladenine promote somatic embryogenesis in date palm (Phoenix dactylifera L.). Sci. Hortic., 89: 291-298. DOI: 10.1016/S0304-4238(00)00244-2

Al-Khayri, J.M. and A.M. Al-Bahrany, 2004. Genotype-dependent in vitro response of date palm (Phoenix dactylifera L.) cultivars to silver nitrate. Sci. Hortic., 99: 153-162. DOI: 10.1016/S03044238(03)00091-8

Al-Khayri, J.M., 2001. Optimization of biotin and thiamine requirements for somatic embryogenesis of date palm (Phoenix dactylifera L.). In vitro Cell. Dev. Biol. Plant., 37: 453-456. DOI: 10.1007/s11627-001-0079-x

Al-Khayri, J.M., 2003. In vitro germination of somatic embryos in date palm: Effect of auxin concentration and strength of MS salts. Curr. Sci., 84: 680-683. www.ias.ac.in/currsci/mar102003/680.pdf

Al-Khayri, J.M., 2005. Date palm Phoenix Dactylifera L. In: Protocols of Somatic Embryogenesis in Woody Plants, Jain, S.M. and P.K. Gupta (Eds.). Springer, Berlin, pp: 309-318. DOI: 10.1007/14020-2985-3_25
Al-Khayri, J.M., 2007. Date Palm Phoenix Dactylifera L. Micropropagation. In: Protocols for Micropropagation of Woody Trees and Fruits Jain, S.M. and H. Haggman (Eds.). Springer, Berlin, pp: 509-526. DOI: 10.1007/978-1-4020-6352-7_46

Al-Khayri, J.M., 2010. Somatic embryogenesis of date palm (Phoenix dactylifera L.) improved by coconut water. Biotechnology, 9: 477-484. DOI: 10.3923/biotech.2010.477.484

Anderson, W.C., 1978. Rooting of tissue cultured rhododendrons. Proc. Int. Plant Prop. Soc., 28: 135-139.

http://www.ipps.org/proceedings/index.htm

Andreu, P. and J.A. Marin, 2005. In vitro culture establishment and multiplication of the Prunus rootstock 'Adesoto 101' (P. insititia L.) as affected by the type of propagation of the donor plant and by the culture medium composition. Sci. Hortic., 106: 258-267. DOI: 10.1016/J.SCIENTA.2005.03.008

Benson, E.E., 2000. Special symposium: In vitro plant recalcitrance: An introduction. In Vitro Cell. Dev. Biol. Plant, 36: 141-148. DOI: 10.1007/s11627000-0029-z

Bonga, J.M., 2004. The effect of various culture media on the formation of embryo-like structures in cultures derived from explants taken from mature Larix decidua. Plant Cell Tiss. Org. Cult., 77: 43-48. DOI: 10.1023/B:TICU.0000016488.79965.B7

Capuana, M., G. Petrini, A. Di Marco and R. Giannini, 2007. Plant regeneration of common ash (Fraxinus excelsior L.) by somatic embryogenesis. In Vitro Cell. Dev. Biol Plant, 43: 101-110. DOI: 10.1007/S11627-007-9030-0

Catapan, E., M.F. Otuki and A.M. Viana, 2001. In vitro culture of Phyllanthus stipulatus (Euphorbiaceae). Revta Brasil Bot. São Paulo, 24: 25-34. DOI: 10.1590/S0100-84042001000100003

Chu, C.C., C.C. Wang, C.S. Sun, C. Hsu and K.C. Yin et al., 1975. Establishment of an efficient medium for anther culture of rice through comparative experiments on the nitrogen sources. Sci. Sin., 18: 659-668. www.scichina.com:8081/sciAe/fileup/PDF/75ya06 59.pdf

Driver, J.A. and A.H. Kuniyuki, 1984. In vitro propagation of paradox walnut rootstock. HortScience, 19: 507-509. $\mathrm{http} / /$ hortsci.ashspublications.org/

Eeuwens, C.J., 1976. Mineral requirements for growth and callus initiation of tissue explants excised from mature coconut palms (Cocos nucifera) and cultured in vitro. Physiol. Plant., 36: 23-28. DOI: 10.1111/J.1399-3054.1976.TB05022.X 
El Hadrami, R.C. and M. Baziz, 1995. Somatic embryogenesis and plant regeneration from shoottip explants in Phoenix dactylifera L. Biol. Plant., 37: 205-211. DOI: 10.1007/BF02913212

El-Shiaty, O.H., S.F. El-Sharabasy and A.H. Abd ElKareim, 2004. Effect of some amino acids and biotin on callus and proliferation of date palm (Phoenix dactylifera L.) Sewy cultivar. Arab J. Biotech., 7: 265-272.

http://www.acgssr.org/BioTechnology/V7N2July2 004/Full_Paper/025.pdf

Ericksson, T., 1965. Studies on growth requirements and growth measurements of cell cultures of Haplopappus gracilis. Physiol. Plant., 18: 976-993. DOI: 10.1111/j.1399-3054.1965.tb06994.x

Eshraghi P., R. Zarghami and M. Mirabdulbaghi, 2005. Somatic embryogenesis in two Iranian date palm cultivars. Afr. J. Biotechnol., 4: 1309-1312. http://www.academicjournals.org/AJB

Estabrooks, T., R. Browne and Z. Dong, 2007. 2,4,5Trichlorophenoxyacetic acid promotes somatic embryogenesis in the rose cultivar 'Livin' Easy' (Rosa sp). Plant Cell Rep., 26: 153-160. DOI: 10.1007/S00299-006-0231-5

Fisichella, M., E. Silvi and S. Morini, 2000. Regeneration of somatic embryos and roots from quince leaves cultured on media with different macroelement composition. Plant Cell Tiss. Org. Cult., 63: 101-107. DOI: 10.1023/A:1006407803660

Fki, L., R. Masmoudi, N. Drira and A. Rival, 2003. An optimised protocol for plant regeneration from embryogenic suspension cultures of date palm, Phoenix dactylifera L., cv. Deglet Nour. Plant Cell Rep., 21: 517-524. DOI: 10.1007/s00299-0020558-5

Gamborg, O.L., R.A. Miller and K. Ojima, 1968. Nutrient requirements of suspension cultures of soybean root cells. Exp. Cell. Res., 50: 151-158. DOI: 10.1016/0014-4827(68)90403-5

Gonzalez, J.M., E. Friero and N. Jouve, 2001. Influence of genotype and culture medium on callus formation and plant regeneration from immature embryos of Triticum turgidum Desf. cultivars. Plant Breeding, 120: 513-517. DOI: 10.1046/j.1439-0523.2001.00661.x

Jain, S.M., N. Dong and R.J. Newton, 1989. Somatic embryogenesis in slash pine (Pinus elliottii) from immature embryos cultured in vitro. Plant Sci., 65: 233-241. DOI: 10.1016/0168-9452(89)90070

Jha, T.B., S. Jah and S.K. Sen, 1992. Somatic embryogenesis from immature cotyledons of an elite Darjeeling tea clone. Plant Sci. 84: 209-213. DOI: 10.1016/0168-9452(92)90136-A
Kao, K.N. and M.R. Michayluk, 1975. Nutritional requirements for growth of Vicia hajastana cells and protoplasts at a very low population density in liquid media. Planta, 126: 105-110. DOI: 10.1007/BF00380613

Karami, O., 2008. Induction of embryogenic callus and plant regeneration in carnation (Dianthus caryophyllus L.). OnLine J. Biol. Sci., 8: 68-72. DOI: 10.3844/OJBSCI.2008.68.72

Khanna, H.K. and S.K. Raina, 1998. Genotype x culture media interaction effects on regeneration response of three indica rice cultivars. Plant Cell Tiss. Org. Cult., 52: 145-153. DOI: 10.1023/A:1006032303195

Khatun, M.M., M.H. Ali and N.V. Desamero, 2003. Effect of genotype and culture media on callus formation and plant regeneration from mature seed scutella culture in rice. Plant Tiss. Cult., 13: 99-107. http://www.baptcb.org/ptc/Full_article/ptc13_2_01 .pdf

Klimaszewska K., Y.S. Park, C. Overton, I. MacEacheron and J.M. Bonga, 2001. Optimized somatic embryogenesis in Pinus strobes L. In Vitro Cell. Dev. Biol. Plant., 37: 392-399. DOI: 10.1007/s11627-001-0069-z

Linsmair, E.M. and F. Skoog, 1965. Organic growth factor requirements of tobacco tissue cultures. Physiol Plant., 18: 100-127. DOI: 10.1111/j.13993054.1965.tb06874.x

Lloyd, G. and B. McCown, 1981. Commerciallyfeasible micropropagation of mountain laurel, Kalmia latifolia, by shoot tip culture. Intl. Plant Prop. Soc. $\quad$ Proc., 30: 421-427. http://www.cabdirect.org/abstracts/19830315515.ht $\mathrm{ml}$;jsessionid=372AB95F7406EF854C297E43D7D C6037\#

Muniran, F., S.J. Bhore and F.H. Shah 2008. Micropropagation of Elaeis guineensis Jacq 'Dura': Comparison of three basal media for efficient regeneration. Indian J. Exp. Biol., 46: 79-82. http://nopr.niscair.res.in/bitstream/123456789/4418 /1/IJEB\%2046(1)\%2079-82.pdf

Murashige, T. and F. Skoog, 1962. A revised medium for rapid growth and bioassays with tobacco tissue cultures. Physiol. Plant., 15: 473-497. DOI: 10.1111/J.1399-3054.1962.TB08052.X

Nas, M.N. and P.E. Read, 2004. A hypothesis for the development of a defined tissue culture medium of higher plants and micropropagation of hazelnuts. Sci. Hortic., 101: 189-200. DOI: 10.1016/J.SCIENTA.2003.10.004

Nitsch, J.P. and C. Nitsch, 1969. Haploid plants from pollen grains. Science, 163: 85-87. DOI: 10.1126/science. 163.3862 .85 
Am. J. Biochem. \& Biotech., 7 (1): 32-42, 2011

Omar, M.S., M.K. Hameed and M.S. Al-Rawi, 1992. Micropropagation of date Palm (Phoenix dactylifera L.). In: Biotechnology in Agriculture and Forestry, Vol. 18, High-Tech and Micropropagation II, Bajaj, Y.P.S. (Ed).. Springer-Verlag, Berlin, pp: 471-492. ISBN: 0387536590

Othmani, A., C. Bayoudh, N. Drira, M. Marrakchi and M. Trifi, 2009. Somatic embryogenesis and plant regeneration in date palm Phoenix dactylifera L., cv. Boufeggous is significantly improved by fine chopping and partial desiccation of embryogenic callus. Plant Cell Tiss. Org. Cult., 97: 71-79. DOI: 10.1007/s11240-009-9500-7

Perez-Tomero, O. and L. Burgos, 2000. Different media requirements for micropropagation of apricot cultivars. Plant Cell Tiss. Org. Cult., 63: 133-141. DOI: 10.1023/A:1006430718024

Pinto, G., Y.-S. Park, S. Silva, L. Neves, C. Araujo and C. Santos, 2008a. Factors affecting maintenance, proliferation and germination of secondary somatic embryos of Eucalyptus globulus Labill. Plant Cell Tiss. Org. Cult., 95: 69-78. DOI: 10.1007/S11240008-9417-6

Pinto, G., S. Silva, Y.-S. Park, L. Neves, C. Araujo and C. Santos, 2008b. Factors influencing somatic embryogenesis induction in Eucalyptus globulus Labill: Basal medium and anti-browning agents. Plant Cell Tiss. Org. Cult., 95: 79-88. DOI: 10.1007/S11240-008-9418-5

Quoirin, M. and P. Lepoivre, 1977. Improved media for in vitro culture of Prunus sp. Acta Hort. (ISHS), 78: 437-442. http://www.actahort.org/books/78/78_54.htm

Rafiq, M., T. Fatima., T. Husnain, K. Bashir and S. Riazuddin, 2005. Effect of different media on callus formation and regeneration of different genotypes of maize (Zea mays L.). Plant Tissue Cult., $\quad$ 15: 57-65. http://www.baptcb.org/ptc/Full_article/ptc15_1_08.pdf

Rakshit, S., Z. Rashid., J.C. Sekhar, T. Fatma and S. Dass, 2010 Callus induction and whole plant regeneration in elite Indian maize (Zea mays L.) inbreds. Plant Cell Tiss. Org. Cult., 100: 31-37. DOI: $10.1007 / \mathrm{s} 11240-009-9613-\mathrm{z}$

Ramage, C.M. and R.R. Williams, 2002. Mineral nutrition and plant morphogenesis. In Vitro Cell. Dev. Biol. Plant, 38: 116-124. DOI: 10.1079/IVP2001269

Schenk, R.U. and A.C. Hildebrandt, 1972. Medium and techniques for induction and growth of monocotyledonous and dicotyledonous plant cell cultures. Can. J. Bot., 50: 199-204. http://www.nrcresearchpress.com/doi/abs/10.1139/ b72-026\#citart1

Sharma, D.R., S. Deepak and J.B. Chowdhury, 1986. Regeneration of plantlets from somatic tissues of the date palm Phoenix dactylifera Linn. Indian J. Exp. $\quad$ Biol., 24: 763-766. http://www.niscair.res.in/sciencecommunication/re searchjournals/rejour/ijeb/ijeb0.asp

Sharma, D.R., R. Kumari and J.B. Chowdhury, 1980. In vitro culture of female date palm (Phoenix dactylifera L.) tissues. Euphytica, 29: 169-174. DOI: $10.1007 / \mathrm{BF} 00037263$

Shirani, S., M. Sariah, W. Zakaria and M. Maziah, 2010. Scalp induction rate responses to cytokinins on proliferating shoot-tips of banana cultivars (Musa spp.). Am. J. Agric. Biol. Sci., 5: 128-134. DOI: 10.3844/ajabssp.2010.128.134

Staritsky, G., 1970. Tissue culture of the oil palm (Elaeis guineensis Jacq) as a tool for its vegetative propagation. Euphytica, 19: 288-292. DOI: 10.1007/BF01904205

Sul, I.W. and S.S. Korban 2004. Effects of salt formulations, carbon sources, cytokinins and auxin on shoot organogenesis from cotyledons of Pinus pinea L. Plant Growth Regul., 43: 197-205. DOI: 10.1023/B:Grow.0000046013.47892.4f

Taha, S.H., S.A. Bekheet and M.M. Saker, 2001. Factors affecting in vitro multiplication of date palm. Biol Plant, 44: 431-433. DOI: 10.1023/A:1012423601467

Thuzar, M., A. Vanavichit, S. Tragoonrung and C. Jantasuriyarat, 2010. Efficient and rapid plant regeneration of oil palm zygotic embryos cv. 'Tenera' through somatic embryogenesis. Acta Physiol. Plant., 33: 123-128. DOI: 10.1007/s11738-010-0526-6

Tripathy, S. and G.M. Reddy, 2002. In vitro callus induction and plantlet regeneration from Indian cotton cultivars. Plant Cell Biotech. Mol. Biol., 3: 137-142.

http://staff.vbi.vt.edu/sutripa/papers/invitro_callus.pdf

Veramendi, J. and L. Navarro, 1996. Influence of physical conditions of nutrient medium and sucrose on somatic embryogenesis of date palm. Plant Cell Tiss. Org. Cult., 45: 159-164. DOI: 10.1007/BF00048760

White, P.R., 1963. The Cultivation of Animal and Plant Cells. 2nd Edn., Ronald Press Co., New York. ISBN: 0826093809, pp: 228.

Zohary, D. and M. Hopf, 2000. Domestication of Plants in the Old World: The Origin and Spread of Cultivated Plants in West Asia, Europe and the Nile Valley. 3rd Edn., Oxford University Press, Oxford, ISBN: 10: 9780198503569 , pp: 328.

Zouine, J. and I. El-Hadrami, 2007. Effect of 2,4-D, glutamine and BAP on embryogenic suspension culture of date palm (Phoenix dactylifera L.). Sci. Hortic., 112(2): 221-226. DOI:10.1016/J.SCIENTA.2006.12.041 